\section{Prospects and challenges of entrepreneurship internationalization on the competitiveness of SMEs}

Gbemi Oladipo Olaore, Bimbo Onaolapo Adejare and Ekpenyong Ekpenyong Udofia

Department of Business Administration, Faculty of Management Science, University of Lagos, Lagos, Nigeria
Prospects and challenges

Received 26 December 2019 Revised 3 May 2020

12 June 2020

13 July 2020

8 September 2020 Accepted 19September 2020

\begin{abstract}
Purpose - Global presence pursuit by Nigerian firms has increased the inquiry into internationalization. While a few implement regional presence, the pros and cons of full internationalization are evaluated. Giving the scarce empirical research, this paper aims to add to scholarly works and knowledge on internationalization and establish regional internationalization as the feasible option for Nigerian firms.

Design/methodology/approach - Random and stratified sampling techniques were used. Data collection was conducted with questionnaire copies and analyzed with confirmatory factor analysis and structural equation model.

Findings - Internationalization strategy enhances small and medium enterprises (SME's) competitive advantage, and full internationalization seems unrealistic for Nigerian firms; however, regional internationalization is the bedrock for full internationalization. Finally, the nature of the Nigerian business environment developed an increased value creation process in SMEs through increased flexibility and problem-solving abilities.

Practical implications - SMEs should internationalize partially, and critically evaluate socio-cultural and institutional environmental challenges in this study, to enable them to strategize for full internationalization.

Originality/value - The study demonstrates that the only way to fast track the internationalization drive of SME's in Nigeria is first to embrace regional internationalization because it is difficult to achieve full internationalization at a go. Then, apply appropriate strategies to embrace full internationalization in the nearest future.
\end{abstract}

Keywords Competitiveness, Socio-cultural factors, Entrepreneurship, Internationalization, Institutional environment, Small- and medium-scales enterprise

Paper type Research paper

\section{Introduction}

Internationalization has become a remarkable trend among Nigerian and African firms in terms of scope, sophistication and scale over the past two decades. The trend has led an

(C) Gbemi Oladipo Olaore, Bimbo Onaolapo Adejare and Ekpenyong Ekpenyong Udofia. Published in Asia Pacific Journal of Innovation and Entrepreneurship. Published by Emerald Publishing Limited. This article is published under the Creative Commons Attribution (CC BY 4.0) licence. Anyone may reproduce, distribute, translate and create derivative works of this article (for both commercial and non-commercial purposes), subject to full attribution to the original publication and authors. The full terms of this licence maybe seen at http://creativecommons.org/licences/by/4.0/legalcode

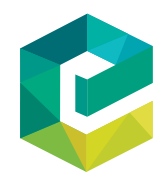

Asia Pacific Journal of Innovation and Entrepreneurship Vol. 14 No. 3,2020 14 No. 3,2020
pp. $303-315$

Emerald Publishing Limited e-ISSN: 2398-7812 p-ISSN: 2071-1395 DOI 10.1108/APJE-12-2019-0094 
APJIE 14,3

increasing number of Nigerian and African firms going across their national borders to conduct transactions (Adeleye and Esposito, 2018; Ibeh et al., 2012). The growth and development in Nigeria and Africa have led to many indigenous industry challengers in regional and domestic markets, creating the term African Rising to celebrate their exploits in innovation, creativity and expansion, while ensuring continued survival (Adeleye and Boso, 2016). For decades back, western multinationals dominated the African business environment, but Nigerian and African firms' internationalization changed this narrative, placing many firms in Nigeria and Africa as serious contenders in this environment. The drive, scope and speed of firms to internationalize have been a very interesting phenomenon (Adeleye and Boso, 2016).

Internationalization drove Nigerian and African firms' expansion, this drive is across diverse industries and sectors (manufacturing and service sector) in the country; including the telecommunications industry, finance industry, the agricultural industry and the oil and gas industry, a few notables among these proudly indigenous firms are Ecobank, United Bank of Africa, Dangote and GT Bank, all from Nigeria to 36, 20, 15 and 11 other countries, respectively, while African notables such as Telkom and MTN expanded into 38 and 24 countries, respectively (Boso et al., 2016; GT bank, 2020). The oil and gas heavyweight, Oando Plc, is another Nigerian firm flying the flag high across national borders (Boso et al., 2016). While we celebrate the successes, there is a need for regional or partial internationalization among African firms, owing to the handful of successes. These successes are predominantly Nigerian and South African firms highlighted by exiting literature (Ibeh et al., 2012). Previous studies on the internationalization of Nigerian and African firms are limited and narrow as most of it focused on economic orientation and how difficult it has been for these firms to achieve full internationalization status (Ibeh et al., 2012). Nowadays, the increasing level of technological advancements coupled with the decrease in the level of barriers to trade, among other things, drive today's business world, and researchers have argued the relevance of the Uppsala model of internationalization in explaining the internationalization process among selected smaller firms, especially in the context of Nigerian and African small- and medium-scale firms (Adeleye and Esposito, 2018). Investigations into contemporary internationalization theories to capture today's dynamic environment is on the rise. These new frontiers explore and explain the implementation processes executed by Nigerian and African success stories (Adeleye and Esposito, 2018).

Internationalization effort in Africa cannot be said to be a palatable one as most firms in Africa (Nigeria inclusive) start small with high mortality rates (Orobia et al., 2020). Hence, internationalization studies are of the essence. The purpose of this study is to explore the extent to which small and medium enterprises (SMEs) have embraced the born global strategy and the Uppsala model, the role institutional environment (IE) plays in the debate and lessons for Nigerian and African SMEs.

\section{Literature review and hypotheses development \\ Born global theory}

The born global theory (BGT) was propounded by Micheal Rennie and was first introduced to the research world through his publication "born global" in 1993 (Covin and Miller, 2014). These firms are usually with distinctive features, such as small staff strength and very limited resources, almost instant internationalization from inception (Oyna and Alon, 2018), heavily information technology (IT) inclined (Johanson and Vahlne, 2009) and management with an international entrepreneurial mindset (Rodrıguez-Serrano and Martın-Armario, 2019). BGT states that firms with distinctive 
capabilities can operate as large multinationals (Oyna and Alon, 2018) and exploit international opportunities without the resources of regular multinationals (Goncalves and Smith, 2019). Several studies have researched such theories possibilities and assert the possibilities of true born global (Johanson and Vahlne, 2009). Researchers previously highlighted several purposes behind the international expansion desires by SMEs and termed it "Born Global" (Ovadje, 2016), and Born Global are universal in their origin and approach, creating the wit to avoid dormancy at the domestic level, which usually occurs in some established companies when pushing for internationalization.

\section{Internationalization}

The desire of mankind to travel as well as do business activities with other parts of the world has been existing for centuries. Therefore, it is expected that it will evolve like any other thing, hence, necessitating the modern drive for business internationalization. Researchers view internationalization from different perspectives; these perspectives give rise to different definitions. Goncalves and Smith (2019) defined internationalization as a means where businesses strive to take their operations across the border. Johanson and Vahlne (1977), defined it as a means by which firms increase their direct and indirect desire and influence to take transactions beyond their borders. Luiz et al. (2017), also defined it as intentionally adapting structures, strategies and resources to meet the firms drive for internationalization. While some researchers are of the opinion that businesses drive internalization, some posit that the government is the invaluable machine behind it all (Code, 2007; Fedorov, 2011), through legislatures and entrepreneurial education.

\section{SMEs and internationalization}

Traditionally, firms that venture into the exportation of goods and services, see it as an internationalization driver. Though exporting is a prominent means of internationalization, firms focus on other means of internationalizing operations; hence, partnerships. Partnering or acquisition and leveraging on the network of firms beyond borders ensures knowledge and technological exchange, as well as an international presence. Globalization and economic changes, coupled with technological advancements, act as the drive for internationalization (Mitgwe, 2006).

The internationalization process model of Johnson and Vahlne (1977) presents a chain of stages inclusive of market knowledge, commitment decision, current activities and market commitment. However, this model was reviewed by the same authors to the 2009 model consisting of knowledge and opportunity followed by relationship commitment decisions, learning creating and trust building and network position.

\section{Uppsala process model of internationalization}

Uppsala process model of internationalization comprises four phases, the model was seen as dynamic because the outcome of one process becomes the input for the next and continues in their sequence throughout the model process. Basically, the model has no start nor end; however, it recognizes two main stages classified into state and change factors. The earlier model places emphasis on activities of firms and their business operations in foreign markets dimension of vulnerability (Johanson and Vahlne, 2009). The 2009 model extensively considers accounts and relationships in the model. 
APJIE 14,3

The state stage in the model considers perspectives briefly settled by its nature in the internationalization model, because the internationalization process is usually outside the firm's system and where the firm lies on the chain is critical to the process. Previously, the perspective stage only considered what was termed as market commitment, but the reviewed version incorporated the association's present conditions, criticizing market commitments myopic view (Johanson and Vahlne, 2009). Knowledge and opportunities make the 1st stage in the model, and it represents the present measure of information available to firms regarding the intended foreign market. Knowledge was added to the updated model of internationalization to highlight its role in opportunity exploitation. The 2009 Uppsala model supports exploiting international opportunities while strengthening internal capabilities, as they are as pivotal as the resources among the network the firm belongs to Johanson and Vahlne, 2009. From this stem, we hypothesize the role of internationalization in SMEs:

H1. Internationalization strategy significantly impacts SMEs competitive performance.

\section{Challenge of global competitiveness on Internationalization - Nigerian and African view}

Nigeria is one of the most populous countries in Africa, which poses opportunities for Nigerian firms to embrace and pursue internationalization, though impediments exist. Three main challenges were addressed in this paper including the challenge of global competitiveness, expertise and limited management and the peculiar challenge(s) of a Nigerian firm. The quest for global competitiveness, encompassing national and corporate level challenges, is encountered daily by Nigerian firms interested in internationalization (Adeleye and Esposito, 2018). At the organisational level, it includes skill set, infrastructural facilities, double taxation and changing regulations (Adeleye and Esposito, 2018). Amankwah-Amoah (2018) also opined that the inability of some organizations to exploit the availability of economies of scale, and poor quality of state services such as electricity and good roads contributed majorly to the challenges faced by most Nigerian firms, as well as African firms, in their quest for internationalization.

Firms also encounter challenges associated with being the new entrant, coupled with being small, as they compete with established brands (who are like sharks in their industry and would strategically suffocate all new entrants if given the opportunity) in their effort toward internationalization (Ngwu Adeleye and Ogbechie, 2015). Looking at the banking industry as a case study, established British and French banks with global footprints and a century long operation were the competitors to all Nigerian and African banks hoping to implement full internationalization (Adeleye et al., 2018), this fierce challenge by the heavy weights of most industries posed and/or currently poses a major challenge to the internationalization of Nigerian firms, though measures to overcome these obstacles are invested upon. Other sectors like the manufacturing, technology and extractive sectors face tougher challenges in their globalization pursuit. Despite environmental challenges, Nigerian firms must brace up, benchmark success stories and step up their performances to truly compete internationally (Ibeh et al., 2012). This leads into the second hypothesis as follows:

H2. Socio-cultural factors as a result of foreign alliance affect SME competitive performance in the home country. 
Native global Nigerian firms battle against the "low quality" tag associated with made-inNigeria goods, especially at their first attempts. It is partly due to the cravings Nigerians had for foreign goods driven by the middle and upper class due to globalization and the superior quality foreign goods once had. Most Nigerian firms struggle to overcome these challenges, which hampers internationalization strides because they need to win the home country's market share before internationalization. While literature recognizes the role of innovativeness in announcing local brands to the globe (Mahmood et al., 2020), conceived notion of the home country target market can hugely dent performance and globalization intention. According to a survey result published in 2017, it revealed the trust level several citizens had in the quality of their indigenous manufacturing firms, inclusive in this massive survey were Tanzanians, Nigerians, Norwegians, Swedish and Finnish citizens, among others. The research showed that the population of Tanzanians, Nigerians, Norwegians, Swedish and Finnish citizens who trusted home-made brands were $8 \%, 15 \%, 74 \%, 64 \%$ and $58 \%$, respectively (Boso et al., 2018a). The disparity in preference between Nigerians and citizens of other developed countries towards their home-grown brand affects performance and internationalization. This perceived trust deficit is a major challenge, and until they are addressed, tackled and overcome, the quest by Nigerian firms for internationalization may remain a far cry from their reality (Luiz et al., 2017).

\section{Ability to navigate institutional voids successfully}

Nigeria is making steady progress in terms of developing her economy though the economy is still faced by challenges posed by the IE and imperfections that leads to market uncertainty and inability to predict the economy (Adeleye and Boso, 2016). The challenges posed by the IE may include weak regulations, underdevelopment, capital constraints, etc. The firms' inability to manage this IE efficiently may lead to serious challenges that will kill the firm's internationalization effort. However, if properly managed, it will give the firm the needed capacity and ability to sustain a competitive advantage over other firms pursuing internationalization (Gao et al., 2017). This statement is supported and backed by the empirical work done by Luiz et al. (2017) that did a study of most successful African enterprises. The study demonstrated the importance of IE complementarity in a firm's quest for internationalization.

The study further stated that firms could capitalize on the knowledge they gathered on how to successfully do business in a weak IE from the domestic front and exploit it to their advantage when they internationalize to similar countries or environments. Considering the unpredictable nature of many African countries, especially regarding economic policies, the Nigerian firm's ability to effectively and efficiently manage the IE will give them the capability and competitive advantage over other firms from other regions or countries (Luiz et al.'s, 2017). Considering the unpredictable nature of most African business environments, the fact that there is the evident presence of underdeveloped institutional environments, the uncertainty and imperfections may benefit Nigerian firms in their quest for internationalization. This is because it gives them a unique opportunity to build capacity and survival instincts in a harsh environment than their competitors from the more advanced countries who have not had the experience or knowledge of how to survive in such an unregulated or imperfect IE (Adeleye and Boso, 2016). This assertion however is scarcely empirically tested and dovetails into the third hypothesis (Figure 1) as follows: 


\section{Methodology \\ Data collection and procedure}

This study examined the prospects and challenges of internationalization on the competitiveness of SME's in Lagos, Nigeria. The study was descriptive and employed questionnaire copies for data gathering from SME owners in Lagos state. SMEs that have operated for over five years and have an international business presence in another country were strictly selected for the study. The justification for selecting SMEs based on years of business operations and internalization presence is due to the nature of the study, as these criteria are deemed important for getting valuable information for the developed questionnaires. The population of registered SMEs in Lagos state, according to Nigerian Bureau of Statistics, (2018), is 8395, and we used judgmental sampling and simple random sampling to select the sample size of 300 participants. The justification for using judgmental sampling is based on the criteria of SMEs that fit the profile of the study, whereas random sampling allows equal participation for all the identified SME owners in Lagos. A total of 300 SME owners were selected in three geographical areas in Lagos state (Lagos Island, Ikeja and Yaba). The justification for selecting these areas in the most vibrant city and economic capital of the country is because they constitute the largest hub of SME owners in Lagos state.

\section{Measures}

The items adapted to develop the research instrument (questionnaire) were from relevant existing literature. Items on the research instrument covering SMEs competitive performance and IE were adapted from the work of Han et al. (1998), While internationalization strategy and socio-cultural factors were adapted from Menguc and Auh (2006). Copies of the research instrument were given to two professors of international business before distribution to assess the items of each constructs in the research instrument, and both professors affirmed that the questionnaire is well developed. The developed research instrument is divided into two sections: demography and items related to constructs section, and a five-point Likert scale of strongly agree, agree, undecided, disagree and strongly disagree was adopted for the study. The stated hypotheses were tested using confirmatory factor analysis (CFA) and structural equation model (SEM). CFA

Figure 1.

Research model

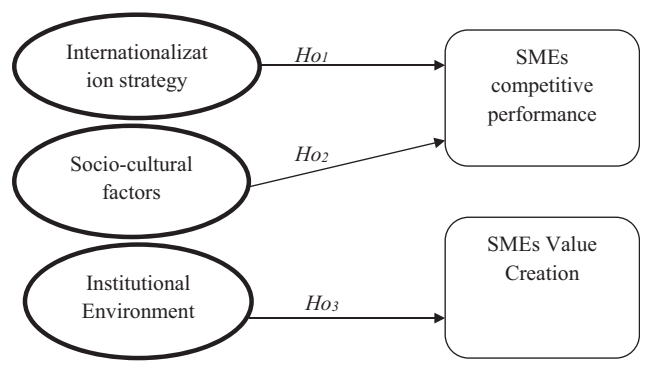


was used to test the reliability and the unidimensionality fitness of the model, whereas SEM was used to test the stated hypotheses.

\section{Results and discussions}

Respondent's demography

The researcher administered 300 questionnaire copies across the selected SME owners in Lagos state Nigeria, and only 293 questionnaires were successfully returned and used for the analysis. The response shows that 39.5\% are female, whereas $60.4 \%$ are male, and this shows that more male attended the questionnaire than female. Also, respondent's age distribution shows that $13 \%$ of the respondents are below 25 years of age, $71.3 \%$ are between 25 and 30 years of age, and $15.7 \%$ are between 31 and 40 years of age. Respondents' marital status shows that $76.1 \%$ are married, whereas $23.9 \%$ are single which shows that a majority of the respondents are married. Similarly, response based on educational qualification of respondent's shows that $67.9 \%$ are HND/BSC holder, $32.1 \%$ have MBA/MSc. Additionally, $23.8 \%$ of respondents have less than 5 years of business ownership experience, $56.7 \%$ have between 6 and 10 years, $12.6 \%$

\begin{tabular}{|c|c|c|c|c|c|c|}
\hline Constructs & Mean & $\begin{array}{l}\text { Standard } \\
\text { deviation }\end{array}$ & $\begin{array}{l}\text { Item-total } \\
\text { correlation }\end{array}$ & $\begin{array}{l}\text { Cronbach's } \\
\text { alpha }\end{array}$ & $\mathrm{CR}$ & AVE \\
\hline \multicolumn{7}{|c|}{ Internationalization strategy } \\
\hline IS1 & 3.46 & 1.124 & 0.641 & 0.850 & 0.831 & 0.556 \\
\hline IS2 & 3.77 & 1.249 & 0.767 & & & \\
\hline IS4 & 3.68 & 1.387 & 0.698 & & & \\
\hline IS5 & 3.79 & 1.310 & 0.664 & & & \\
\hline IS6 & 4.12 & 1.432 & 0.724 & & & \\
\hline \multicolumn{7}{|c|}{ SMEs competitive performance } \\
\hline SCP2 & 3.78 & 1.437 & 0.562 & 0.821 & 0.798 & 0.505 \\
\hline SCP3 & 4.04 & 1.267 & 0.783 & & & \\
\hline SCP4 & 4.22 & 1.202 & 0.601 & & & \\
\hline SCP5 & 3.92 & 1.197 & 0.650 & & & \\
\hline \multicolumn{7}{|c|}{ Institutional environment } \\
\hline IE2 & 3.26 & 1.080 & 0.679 & 0.857 & 0.748 & 0.503 \\
\hline IE3 & 3.36 & 0.989 & 0.797 & & & \\
\hline IE4 & 3.22 & 1.026 & 0.721 & & & \\
\hline IE5 & 4.23 & 0.897 & 0.679 & & & \\
\hline \multicolumn{7}{|c|}{ SMEs value creation } \\
\hline SVC1 & 3.08 & 1.060 & 0.828 & 0.892 & 0.921 & 0.745 \\
\hline $\mathrm{SVC} 2$ & 3.08 & 1.052 & 0.819 & & & \\
\hline SVC3 & 3.14 & 1.095 & 0.811 & & & \\
\hline SVC4 & 3.17 & 1.095 & 0.812 & & & \\
\hline \multicolumn{7}{|c|}{ Socio-cultural factors } \\
\hline SCF1 & 4.10 & 0.649 & 0.615 & 0.790 & 0.863 & 0.678 \\
\hline SCF2 & 4.03 & 0.812 & 0.682 & & & \\
\hline SCF3 & 3.96 & 0.824 & 0.756 & & & \\
\hline SCF4 & 3.99 & 0.754 & 0.718 & & & \\
\hline SCF6 & 4.04 & 0.669 & 0.744 & & & \\
\hline
\end{tabular}

Notes: CR: Composite reliability; AVE: Average variance extracted
Prospects and challenges

309

Table 1. Reliability measures 
APJIE 14,3

have between 11 and 15 years, whereas $6.8 \%$ have above 15 years of business experience.

\section{Confirmatory factor analysis}

Table 1 shows the unidimensionality results from CFA such as mean, standard deviation and item-total correlation of the items on the questionnaire, as well as Cronbach's alpha reliability, composite reliability (CR) and average variance extracted (AVE) figures for each construct in the model.

Testing for the fitness of the model and instrument used to conduct the analysis. The study conducted confirmatory factor analysis (CFA) to determine the goodness of fits of the model. The observed variable of internalization strategy had eight items, out of which three items (IT3, IT7 and IT8) were deleted. The variable SMEs competitive performance had six items out of which two items were deleted (SCP1 and SCP6). The variable IE had seven items and three items were deleted (IE1, IE5 and IE6). The variable SMEs value creation (SVC) and socio-cultural factors had five items each and one item was deleted from each variable (SVC5 and SCF5). The results of the CR and the AVE for each of the variable tested is above 0.70 and 0.50 which is the baseline threshold as recommended by Bagozzi and Yi (2012) and this shows that the model is reliable.

Furthermore, the threshold of acceptance of Cronbach's alpha is 0.70 as recommended by Nunnally (1978), thus, the results shows that each of the variable Cronbach's alpha is above the threshold for acceptance. Generally, the measurement model fit the data well as $\left(\chi^{2} / \mathrm{df}=2.748\right.$, IFI, $=0.900$, CFI $=0.919$, TLI $=0.952$ and RMSEA $=0.078)$ which according to Nusair and Hua (2010) are a good indication of measurement fitness. Where, $\left(\chi^{2} / \mathrm{df}\right)$ represents the chi-square, (IFI) represents incremental fits index, (CFI) represents comparative fits index, (TLI) represents Tucker Lewis index and (RMSEA) represents roots mean square error of approximation. This shows that the model is very fits for conducting structural equations model for testing of the hypotheses stated in the study.

\section{Hypotheses testing (path modelling/structural equation model)}

Three hypotheses are posited in this study and literature confirms that when $p<0.05$, $p<0.01$ and $p<0.001$ are a good indication that there is a significant relationship among measured and latent variables which then lead to either accepting or rejecting a hypothesis Chinomona et al. (2010) (Table 2).

The regression weight showing the significant relationship between both the independent and dependent variable implies that there is a strong positive relationship between internationalization strategy (IS) and SMEs competitive performance (SCP) at 0.654 . The $P$ value shows a 0.05 confidence level which signify that the hypothesis is supported and significant. Thus, we accept $H 1$. The finding however aligned with Olejnik and Swoboda (2012), and Madsen et al. (2015) who found that SMEs internalization experience is healthy for continuous competitive performance and sustainability of firms

Table 2.

Result of hypotheses Hypothesis

\begin{tabular}{lccc} 
Relational path & Coefficients & $p$ value & Remark \\
\hline IS $\rightarrow$ SCP & 0.654 & 0.000 & Supported \\
SCF $\rightarrow$ SCP & 0.734 & 0.000 & Supported \\
IE $\rightarrow$ SVC & 0.522 & 0.000 & Supported \\
\hline
\end{tabular}


both in the local and foreign markets. The regression weight showing the significant relationship between both the independent and dependent variable implies that there is a strong positive relationship between Socio-Cultural Factors (SCF) and SMEs competitive performance (SCP) at 0.734 . The $P$ value shows a 0.05 confidence level which signify that the hypothesis is supported and significant. Thus, we accept H2. The finding of the study corroborates the works of Torres-Ortega et al. (2015), and Kazumi and Kawai (2017) who found that the extent of SMEs understanding of the socio-cultural factors in the host country of business interest have influence on their competitive performance. The regression weight challenges showing the significant relationship between both the independent and dependent variable implies that there is a strong positive relationship between IE and SVC at 0.522 . The $p$ value shows a 0.05 confidence level which signify that the hypothesis is supported and significant. Thus, we accept H3. The finding is consistent with the work of Covin and Miller (2014), Kazumi and Kawai (2017) who states that SMEs from low economic states tend to do better than SMEs in good economic regions when they come to such regions.

\section{Discussion}

The result of $H 1$ revealed a positive, significant relationship between SMEs competitive advantage and the internationalization strategy to achieve competitive performance. The finding aligns with that of Adeleye and Esposito (2018) whose results reveal that most Nigerian firms tend to adopt the Uppsala model compared to the born global strategy. Nigerian firms are more receptive towards incremental, and sequential approach in regional internationalization. The study equally aligns with results of Adams et al. (2018) who also corroborated the assertion stating that most Nigerian firms are more aggressive in establishing regional presence, than they are in achieving global presence when regional operations is achieved. Citing a sense of premature satisfaction at the regional level. Perhaps, because regional is easier than global internationalization (Adeleye and Esposito, 2018).

Secondly, socio-cultural factors positively affect SMEs' competitive performance in the home country due to the foreign alliance. The findings are in contrast to the result of Adeleye et al. (2018) who revealed that socio-cultural factors had an adverse impact on competitive performance of SMEs. Studies done by Barungi et al. (2016) also support the findings that socio-cultural factors play a major role in the internationalization effort of SMEs in Nigeria and the inability of the SMEs to fully mitigate against these factors made many SMEs in Nigeria remain on the local front alone and downplayed their internationalization efforts.

The third hypothesis reveals a significant relationship between the IE and the Nigerian SMEs' value creation. The unpredictable nature of Nigeria's institutional environment, coupled with bad infrastructure over the years, has been a major issue for local firms. Lack of infrastructure, issues of double taxation, insecurity, partial regulatory government agencies, bribery and corruption are some of the numerous issues Nigerian firms contend with just to survive. This issue has also prevented a lot of Nigerian firms from Internationalizing, as corroborated by Ngwu et al. (2015) whose work titled "Africa to Africa Internationalization: Rhetoric, reality and risk of intraAfrican regional expansion” exposed how the IE has adversely affected the operations and daily survival of Nigerian firms to the point where some of them closed their operations in Nigeria and moved to neighboring countries (Ghana, Togo and Benin) with business friendlier environments. Having said these, the findings of this study show that the nature of the Nigerian business environment sparked a resilience like no other in SMEs value creation tendencies. And these capabilities horned over time from 
doing business in harsh environments came in handy when dealing in environments with a business friendlier ecosystem. They seemed more flexible in operations and resourceful in problem-solving than SMEs from less challenging institutional environments.

\section{Conclusion}

This article made significant contributions to the existing literature on internationalization and issues surrounding the challenges faced by Nigerian firms in their quest for internationalization by showing how some of the firms in Nigeria have been able to adjust to the challenges and the numerous prospects that can be harnessed by a firm in the international market. This article also took a critical look at the Internationalization process model by Johnson and Vahlne examining the 1977 model, what the elements in the model stand for when internationalization is discussed and the new internationalization model by same authors in 2009 explaining some changes that necessitated the new model and how the model has been able to fully capture issues relating to the internationalization process (Johanson and Vahlne, 2009). This article also pays special emphasis on some major Nigerian firms and how far they have gone in their internationalization effort.

While some struggled with regional internationalization, regionally successful Nigerian firms understudied revealed a strong link between capacities developed from conducting business in Nigeria and their value creation process. This study reveals that most of the Nigerian firms under consideration have only been able to achieve regional internationalization and none can be said to have fully been able to achieve what can be termed full internationalization (Ovadje, 2016). Considering the dynamic nature of the institutional environment, fast-paced nature of the environment and the numerous issues Nigerian firms contend with in their daily business operations, there is a strong need to further subject this study to robust empirical studies preferably a mixed methodology to these emerging phenomena on prospects and challenges associated with internationalization by Nigerian firms. This is particularly important because most of the research questions have scarcely been empirically tested to draw a conclusion.

The recommendations of this study include as follows. Firstly, Nigerian firms should focus more energy and resources towards regional internationalization, as that appears to be the faster way to achieve internationalization with less hurdles. Plus, it presents a familiar geographic zone to Nigerian firms, and the doggedness of surviving the Nigerian business environment will aid acclimatization and subsequent success. Also, Nigerian firms should ensure the right policies should be put in place to ensure effective and efficient resource utilization, waste minimization, merit-based staffing and promotion and successful internationalization. The result encourages Nigerian firms pursuing internationalization to come up with a strategic business plan aimed at boosting their presence internationally and strategic policies capable of adding value to the firm, shareholders and stakeholders. The pursuit of internationalization by Nigerian firms should be birth by the desire of the firms to fully pursue internationalization and not just as a status symbol to show off, which the firm may not actually pay full attention to thereby killing the essence of the investment. Finally, the government and regulatory authorities should also address the rigid double taxation system in Nigeria and also give more support to firms pursuing internationalization since their success across the national boarders will also increase employment and revenue for government through taxes. 


\section{References}

Adams, K., Nyuur, R., Ellis, F. and Debrah, Y. (2018), "South African MNCs' HRM systems and practices at the subsidiary level: insights from subsidiaries in Ghana", Journal of International Management, Vol. 23 No. 2, pp. 180-193.

Adeleye, I. and Boso, N. (2016), "Africa-to-Africa internationalization: future trends and research avenues", in Adeleye, I. White, L. and Boso, N. (Eds), Africa-to-Africa Internationalization: Key Issues and Outcomes, Palgrave Macmillan, New York, NY, pp. 35-65.

Adeleye, I. and Esposito, M. (2018), Africa's Competitiveness in the Global Economy, Palgrave Macmillan, New York, NY.

Adeleye, I., Ngwu, F., Iheanachor, N., Esho, E., Oji, C., Onaji-Benson, T. and Ogbechie, C. (2018), "Banking on Africa: can emerging pan-African banks outcompete their global rivals?", in Adeleye, I. and Esposito, M. (Eds), Africa's Competitiveness in the Global Economy, Palgrave Macmillan New York, NY, pp. 113-136.

Amankwah-Amoah, J. (2018), "Why are so many African companies uncompetitive on the global stage? Insights from the global airline industry", in Adeleye, I. and Esposito, M. (Eds), Africa's Competitiveness in the Global Economy, Palgrave Macmillan, New York, NY: pp. 195-216.

Bagozzi, R.P. and Yi, Y. (2012), "Specification, evaluation, and interpretation of structural equation models", Journal of the Academy of Marketing Science, Vol. 40 No. 1, pp. 8-34.

Barungi, B., Ogunleye, E. and Zamba, C. (2016), "Nigeria 2015: African eco-nomic outlook", available at: africaneconomicoutlook.org

Boso, N., Adeleye, I., Ibeh, K. and Chizema, A. (2018a), "The internationalization of African firms: opportunities, challenges, and risks", Thunderbird International Business Review, Vol. 61 No. 1, pp. 1-8.

Boso, N., Adeleye, I. and White, L. (2016), "Africa-to-Africa internationalization: emerging trends and key issues", in Adeleye, I. White, L. and Boso, N. (Eds), Africa-to-Africa Internationalization: Key Issues and Outcomes, Palgrave Macmillan, New York, NY: pp. 3-34.

Chinomona, R., Lin, J.Y.C., Wang, M.C.H. and Cheng, J.M.S. (2010), "Soft power and desirable relationship outcomes: the case of Zimbabwean distribution channels", Journal of African Business, Vol. 11 No. 2, pp. 182-200.

Code, P.K. (2007), "Nurturing the entrepreneurial spirit - developing teachers' economic knowledge and entrepreneurial dispositions", Management Review: An International Journal, Vol. 2 No. 2, pp. 73-97.

Covin, J.G. and Miller, D. (2014), "International entrepreneurial orientation: conceptual, considerations, research themes, measurement issues, and future research directions", Entrepreneurship Theory and Practice, Vol. 38 No. 1, pp. 11-44.

Fedorov, A.A. (2011), "Entrepreneurship and economic globalisation in Primorsky region: problems and decision ways", Management Review: An International Journal, Vol. 6 No. 2, pp. 47-61.

Gao, C., Zuzul, T., Jones, G. and Khanna, T. (2017), "Overcoming institutional voids: a reputation-based view of long-run survival”, Strategic Management Journal, Vol. 38 No. 11, pp. 2147-2167.

Goncalves, M. and Smith, C.E. (2019), "Lusophone-African SME internationalization: a case for born global and international joint ventures", Journal of Transnational Management, Vol. 24 No. 3, pp. 231-258.

GT Bank (2020), "Our company”, available at: www.gtbank.com/about/our-company/subsidiaries (assessed 5 April 2020).

Han, K.J., Kim, N. and Srivastava, R.K. (1998), "Market orientation and organizational performance: is innovation a missing link?", Journal of Marketing, Vol. 62 No. 4, pp. $30-45$.

Ibeh, K., Wilson, J. and Chizema, A. (2012), "The internationalization of African firms 1995-2011: review and implications", Thunderbird International Business Review, Vol. 54 No. 4, pp. 411-427. 
APJIE 14,3

Johanson, J. and Vahlne, J. (1977), "The internationalization process of the firm: a model of knowledge development and increasing foreign market commitments", Journal of International Business Studies, Vol. 8, pp. 23-32, available at: https://ink.springer.com/ journal/41267

Johanson, J. and Vahlne, J.E. (2009), "The Uppsala internationalization process model revisited: from liability of foreignness to liability of outsidership", Journal of International Business Studies, Vol. 40 No. 9, pp. 1411-1431.

Kazumi, T. and Kawai, N. (2017), "Institutional support and women's entrepreneurial self-efficacy”, Asia Pacific Journal of Innovation and Entrepreneurship, Vol. 11 No. 3, pp. 345-365.

Luiz, J., Stringfellow, D. and Jefthas, A. (2017), "Institutional complementarity and substitution as an internationalization strategy: the emergence of an African multinational giant", Global Strategy Journal, Vol. 7 No. 1, pp. 83-103.

Madsen, T.K., Sorensen, H.E. and Torres-Ortega, R. (2015), "The market orientation of domestic and international new ventures", Advances in International Marketing, Vol. 25, pp. 21-44.

Mahmood, T.A.M.T., Mammun, A.A. and Ibrahim, D.M. (2020), "Attitude towards entrepreneurship: a study among asnaf millennials in Malaysia", Asia Pacific Journal of Innovation and Entrepreneurship, Vol. 14 No. 1, pp. 2-14.

Menguc, B. and Auh, S. (2006), "Creating a Firm-Level dynamic capability through capitalizing on market orientation and innovativeness", Journal of the Academy of Marketing Science, Vol. 34 No. 1, pp. 63-73.

Mitgwe, B. (2006), "Theoretical milestones in international business: the journey to international entrepreneurship theory", Journal of International Entrepreneurship, Vol. 4 No. 1, pp. 5-25.

Ngwu, F., Adeleye, I. and Ogbechie, C. (2015), "Africa-to-Africa internationalization: Rhetoric, reality and risks of intra-African regional expansion”, in Nwankwo, S. and Ibeh, K. (Eds), The Routledge Companion to Business in Africa, Routledge, New York, NY, pp. 9-31.

Nigerian Bureau of Statistics (2018), "National survey of micro, small, and medium enterprises (MSMEs) 2017", available at: www.nigeriastat.gov.ng (accessed 20 April 2020).

Nunnally, J.C. (1978), Psychometric Theory, 1st ed., Mcgraw Hill, New York, NY.

Nusair, K. and Hua, N. (2010), "Comparative assessment of structural equation modeling and multiple regression research methodologies: e-commerce context”, Tourism Management, Vol. 31 No. 3, pp. 314-324.

Olejnik, E. and Swoboda, B. (2012), "SMEs' internationalisation patterns: descriptive, dynamics and determinants", International Marketing Review, Vol. 29 No. 5, pp. 466-495.

Orobia, A.L., Tusiime, I., Mwesigwa, R. and Ssekiziyivu, B. (2020), "Entrepreneurial framework conditions and business sustainability among the youth and women entrepreneurs", Asia Pacific Journal of Innovation and Entrepreneurship, Vol. 14 No. 1, pp. 60-75.

Ovadje, F. (2016), "The internationalization of African firms: effects of cultural differences on the management of subsidiaries", Africa Journal of Management, Vol. 2 No. 2, pp. 117-137.

Oyna, S. and Alon, I. (2018), “A review of born globals", International Studies of Management and Organization, Vol. 48 No. 1, pp. 157-180.

Rodrıguez-Serrano, A.M. and Martı-Armario, E. (2019), "Born-global SMEs, performance, and dynamic absorptive capacity: evidence from Spanish firms", Journal of Small Business Management, Vol. 57 No. 2, pp. 298-326.

Torres-Ortega, R., Rialp-Criado, A., Rialp-Criado, J. and Stoian, M.-C. (2015), "How to measure bornglobal firms' orientation towards international markets?", Revista Española de Investigación de Marketing ESIC, Vol. 19 No. 2, pp. 107-123, doi: 10.1016/j.reimke.2015.04.001. 


\section{Further reading}

Boso, N., Annan, J., Adeleye, I., Iheanachor, N. and Narteh, B. (2018b), "Investigating the paths from export strategic orientations to export performance: the role of export resource transformation capability”, Thunderbird International Business Review, Vol. 60 No. 2, pp. 207-230.

Ecobank (2020), "Ecobank branches", available at: https://ecobank.com/personal-banking/ways-tobank/branches (assessed 5 April 2020).

\section{Corresponding author}

Bimbo Onaolapo Adejare can be contacted at: bimboadejare@gmail.com

For instructions on how to order reprints of this article, please visit our website: www.emeraldgrouppublishing.com/licensing/reprints.htm Or contact us for further details: permissions@emeraldinsight.com 